Original Research Paper

\title{
Budidaya Rumput Laut Pada Kedalaman Berbeda
}

\author{
Nunik Cokrowati ${ }^{*}$, Dewi Nur'aeni Setyowati ${ }^{1}$ \\ ${ }^{1}$ Program Studi Budidaya Perairan, Universitas Mataram
}

*Corresponding Author: Nunik Cokrowati, Program Studi Budidaya Perairan, Universitas Mataram, Indonesia;

Email: nunikcokrowati@unram.ac.id

\begin{abstract}
Provinsi Nusa Tenggara Barat memiliki areal potensial untuk budidaya rumput laut seluas 35.000 Ha dengan produksi rumput laut pada tahun 2017 sebanyak 13,39 juta ton. Perairan Seriweh Kabupaten Lombok Timur merupakan perairan yang dimanfaatkan untuk budidaya rumput laut dan menyumbang produksi rumput laut tersebut. Tujuan kegiatan ini adalah untuk mengintroduksi budidaya rumput laut dengan kedalaman yang berbeda untuk menghasilkan rendemen karaginan yang optimal. Harga rumput laut kering seharusnya ditetapkan berdasarkan rendemen karaginannya, namun hal tersebut belum berlaku di Provinsi Nusa Tenggara Barat. Meskipun demikian pembudidaya harus tetap berusaha untuk memproduksi rumput laut dengan rendemen karaginan optimal.
\end{abstract}

Kata kunci: Kappaphycus alvarezii, produksi, kedalaman, harga, Nusa Tenggara Barat

\section{Pendahuluan}

Budidaya rumput laut yang dilakukan di perairan Seriweh menggunakan metode longline dengan spesies yang dibudidayakan adalah Eucheuma cottonii. Perairan Seriweh berbentuk teluk dan merupakan perairan yang produktif. Namun akibat dari kegiatan budidaya rumput laut yang terus menerus dilakukan selama 10 tahun terakhir maka pertumbuhan rumput laut saat ini kurang optimal. Sehingga kegiatan budidaya rumput laut di Teluk Seriweh harus diberikan jeda. Tidak hanya pengaturan jeda budidaya, namun perlu juga dilakukan metode yang tepat untuk mendapatkan rendemen karaginan yang optimal. Harga rumput laut kering seharusnyaditentukan oleh rendemen karaginan, namun hal tersebut belum diterapkan oleh pembeli rumput laut di Provinsi Nusa Tenggara Barat. Berdasarkan hasil penelitian Cokrowati (2018) menerangkan bahwa budidaya rumput laut di perairan seriweh dapat menghasilkan rendemen karaginan yang optimal pada kedalaman $30 \mathrm{~cm}$ diatas permukaan air laut. Metode tersebut harus disampaikan kepada pembudidaya rumput laut di Seriweh, sehingga mereka dapat menghasilkan rumput laut dengan rendemen karaginan yang optimal. Produksi rumput laut juga diharapkan dapat dilakukan kontinyu tetapi harus tetap memperhatikan keberlanjutan pemanfaatan perairan Seriweh.

\section{Metode Pelaksanaan}

Kegiatan ini dilaksanakan pada bulan Juni 2018 di perairan Seriweh Lombok Timur dengan mitra adalah pembudidaya rumput laut yang ada di perairan Seriweh. Metode yang digunakan pada kegiatan ini adalah dengan demplot secara langsung melakukan budidaya rumput laut dengan menggunakan longline. Introduksi metode budidaya tersebut dilakukan dengan demplot langsung dan pendampingan selama proses budidaya.

\section{Hasil dan Pembahasan}

Kegiatan introduksi budidaya rumput laut dengan menggunakan longline dan pada kedalaman yang berbeda di lakukan di perairan Semirang yang ada di Teluk Seriweh. Budidaya rumput laut pada kedalaman yang berbeda, diperlukan untuk efisiensi 
penggunaan lahan dan untuk memperoleh kadar karaginan yang optimal pada rumput laut. Karena selama ini budidaya rumput laut di lokasi tersebut hanya memanfaatkan permukaan perairan saja. Bibit yang digunakan adalah rumput laut jenis Kappahycus alvarezii. Rumput laut jenis tersebut merupakan rumput laut yang secara kontinyu dibutuhkan oleh pasar. Bibit yang digunakan merupakan bibit yang sudah terseleksi terlebih dahulu dengan kriteria bibit yang baik dan sehat adalah thalus segar, berwarna coklat kemerahan, tidak ada bercak putih, bau segar, dan tidak mudah patah. Bibit yang ditanam menggunakan berat ratarata 100 gram. Bibit diikat pada masing masing tali ris menggunakan tali rafia. Pengikatan bibit dilakukan pada pagi hari sebelum matahari berada pada ketinggian maksimal. Pengikatan bibit diklakukan oleh kelompok mitra sebagaimana gambar berikut ini.

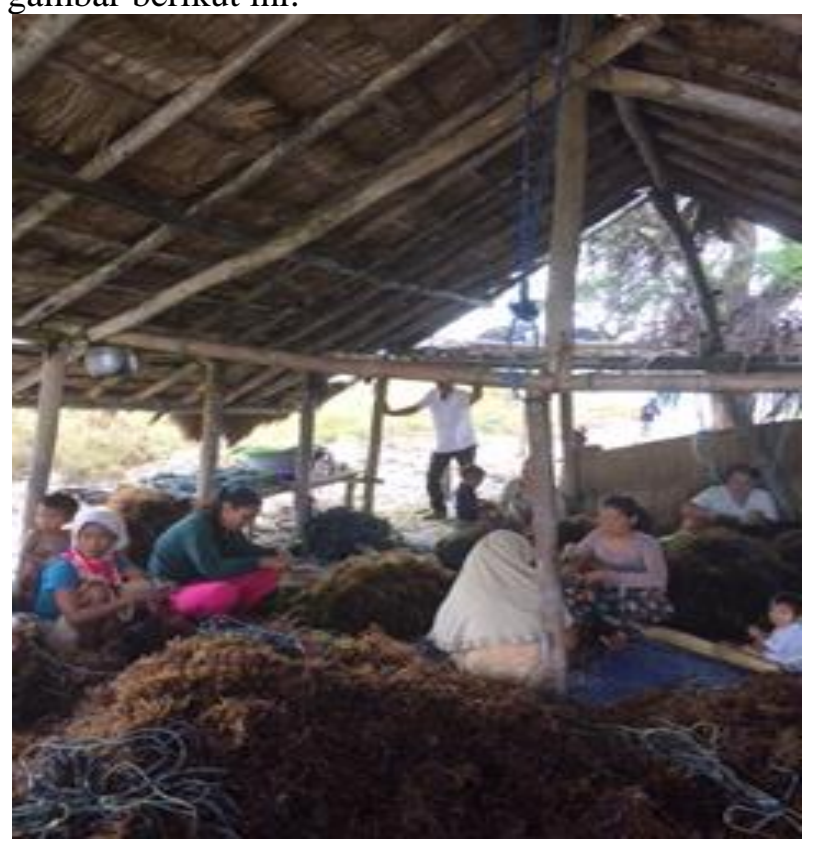

Gambar 1. Pengikatan bibit rumput laut oleh pembudidaya

Sumber: Dokumentasi pribadi, 2018.

Pengikatan bibit tidak boleh dilakukan pada tempat yang panas dan tidak boleh dilakukan secara lambat. Pengikatan bibit harus dilakukan di tempat yang terlindung oleh matahari atau dilakukan sebelum matahari terbit. Hal tersebut untuk menghindari rumput laut stres dan menghindari kematian bibit. Bibit yang telah terikat di tali ris, segera dimasukkan atau di rendam ke laut dan segera diikatkan ke longline. Berikut adalah gambar demplot budidaya rumput laut pada longline.

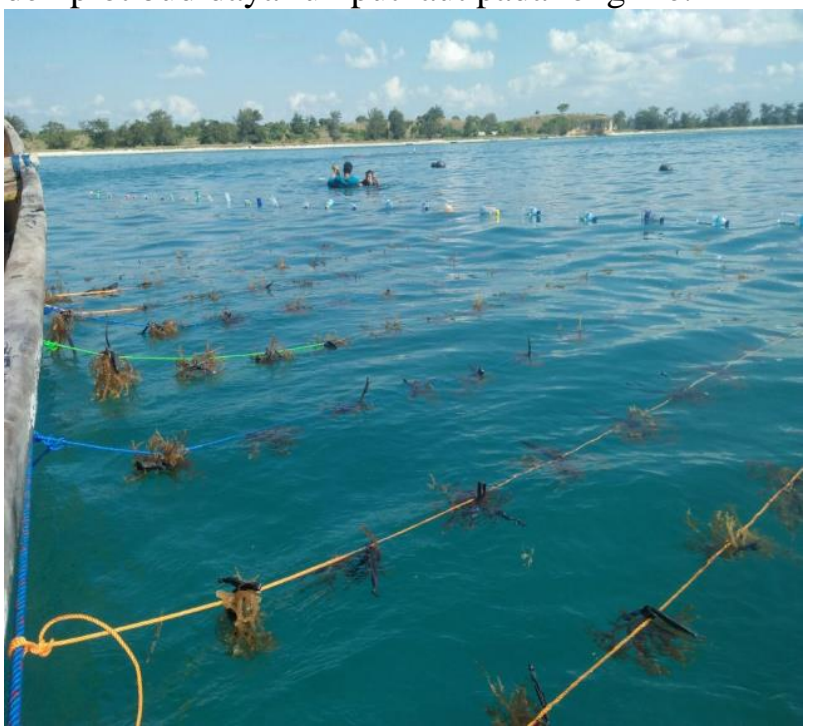

Gambar 2. Budidaya rumput laut dengan sistem longline Sumber: Dokumentasi Pribadi, 2018.

Rumput laut dibudidayakan selama 45 hari dan dilakukan pemeliharaan serta kontrol terhadap hama dan penyakit. Pemeliharaan dilakukan dengan cara pengontrolan oleh pembudidaya setiap hari dengan menggunakan perahu. Jika longline dan rumput laut banyak terdapat kotoran atau biota laut lainnya yang menempel maka harus dilakukan pembersihan dengan cara menggoyang-goyangkan longline. Pengontrolan juga dilakukan dengan cara mengamati pertumbuhan thalus sehingga dapat dilakukan tindakan pencegahan rontoknnya talus akibat pertumbuhan yang cepat sehingga talus tidak patah akibat beratnya thallus.

\section{Kesimpulan}

Budidaya rumput laut pada berbagai kedalaman telah diintroduksikan kepada pembudidaya rumput laut di Seriweh dan dapat dilakukan dengan mudah oleh pembudidaya. Budidaya rumput laut pada beberapa kedalaman dapat memaksimalkan pemanfaatan ruang laut.

\section{Saran}

Teknologi budidaya rumput laut sebaiknya disesuaikan dengan kondisi ekologi perairan. 


\section{Ucapan Terima Kasih}

Ucapan terima kasih disampaikan kepada Universitas Mataram yang telah mengalokasidan dana BOPTN Universitas Mataram untuk mendanai kegiatan ini.

\section{Daftar Pustaka}

Anggadiredja, J.T., 2008. Rumput Laut: pembudidayaan, pengolahan\&pemasaran komoditas perikanan potensial. Penebar Swadaya. Jakarta.

Cokrowati, Nunik, 2016. Buku Ajar Teknologi Budidaya Rumput Laut. Masyarakat Akuakultur Indonesia (MAI Publishing). Semarang.

Dinas Kelautan dan Perikanan Provinsi Nusa Tenggara Barat, 2017. Statistik Perikanan Budidaya. Dinas Kelautan dan Perikanan Provinsi Nusa Tenggara Barat. Mataram Lombok Nusa Tenggara Barat.

Huda, M.I., dkk., 2012. Ekstraksi Karaginan dari rumput laut (Eucheuma spinosum) dengan Variasi suhu pelarurt dan waktu operasi.

Poncomulyo, Taurino, dkk., 2006. Budidaya dan Pengolahan Rumput Laut. Agromedia. Jakarta. 